\title{
The Factors Affecting Pupils' Performance in EFL Classes: A Sociolinguistic Dimension
}

\author{
Belaid Louiza $^{1} \&$ Sarnou Hanane ${ }^{2}$
}

${ }^{1 \& 2}$ Mostaganem University, English Department, Faculty of Foreign Languages, Algeria Correspondence: Belaid Louiza, Mostaganem University, Algeria. Email: belaidlouiza38@yahoo.com

Received: April 11, 2019

Accepted: May 26, 2019

Online Published: June 1, 2019

doi: 10.23918/ijsses.v5i4p87

\begin{abstract}
The present work investigates the effects of socio-linguistic factors on pupils' school performance in the English language subject. It examines the impact of the pupils' linguistic and social background on their academic performance. The major objective of this work is to identify the reasons behind low performance in English, especially among male pupils. Hence, the research instruments used to collect data are descriptive and qualitative; they are an observation and a questionnaire, mainly designed for pupils from all educational streams, scientific and literary. Our sample is comprised of 80 pupils who are selected from Mohamed Boudhiaf Secondary School, final classes, in Tissemsilt- Algeria. We concluded that school failure is linked to the low level of learners in languages, the number of females that is increasing in the class, besides the non-stimulating perspectives of the speech community where pupils inhabit.
\end{abstract}

Keywords: Sociolinguistic Factor, Linguistic Background, School Failure, Educational Level, Speech Community

\section{Introduction}

Achievement at school has always been the concern of teachers and learners. A debate over pupils' performance is warrant consideration. Not all learners achieve successful results at school and the factors that might contribute to this phenomenon vary contextually. In this prospect, our research investigates the impact of sociolinguistic factors on pupils' performance. To go deeply through this research, our aim is to assess school failure from a sociolinguistic perspective. The pupils' low performance in the English language subject is observed in the secondary school of Mohamed Boudhiaf. It is noticed that girls outperform boys in oral and written performance. In fact, underachievement entails a switch in performance and a discrepancy in achievement, and this perspective varies from one school to another, and from one learner to another; that is to say, pupils' weak performance is not measured similarly by schools. Thus, the above mentioned phenomenon is context-bound. In this regard, the main query in this study searches for the factors which contribute to gender school failure. We hypothesise that gender and pupils' inefficient linguistic background might be strong causes that lead to failure. The major objective of this research is to detect the reasons behind underachievement in the English language subject in the secondary school, especially among boys. Hence, the research tools used to collect data are qualitative and descriptive; they are an observation and a questionnaire, mainly for pupils. The aim of 
the observation is to identify the variables that influence learners' achievement while, the aim of the questionnaire is to give the researcher a perception on how English is being taught and learned, and what difficulties learners are encountering. 80 pupils are randomly selected from Mohamed Boudhiaf secondary school, Tissemsilt- Algeria. Pupils' low performance is recognized throughout years in all streams; this latter is associated to the lack of motivation among learners, besides the deficiency of perquisite knowledge of the English language that is supposed to be taught in the middle school, further females' number in the classroom is increasing and this could exclude males from school unintentionally. Besides, the social environment which has a strong effect on pupils' pursuit of their studies. Scholars like Castejon (2016) proposed how to identify, appropriately, low performers from high performers putting emphasis on agreements among educators in grading. Conversely, Giavrimis and Papanis (2008) shed light on the impact of social background on pupils' achievement claiming that parental economy influences children school success. Additionally, Negadi (2015) stresses the importance of the Algerians linguistic diversity whereby French could be a necessary code to be used in order to foster English teaching/ learning.

\section{Theoretical Framework}

\subsection{Underachievement}

In the school context, an underachiever is used not only to refer to individuals but sometimes groups. These groups may descent from disadvantaged backgrounds regardless of their type of intelligence (IQ). An underachiever is someone who is less successful than they should be at school or at work. In fact, there is a myriad of explanations in the literature review and many scholars tackled the issue of underachievement or low performance and have defined it from different perspectives.

Dowdall \& Colangelo (1982) as cited in Griffin (1988) claim that learners, who demonstrate high capacity in the classroom and are active in learning, but not performing satisfactorily as expected in a written examination or a formative test, are considered as underachievers. On the one hand, achievement is argued to be "the level of accomplishment that is 'evaluated' by teachers, tests... in other words, any but the most idiosyncratic definition of achievement must also depend upon value judgements, opinions, and standards external to the achiever" (Harvey \& Sander, 1988, p. 2). The majority of teachers are familiar with the concept 'accomplishment' rather than 'achievement'; learners who are supposed to be accomplishers are achievers. So, this term is preserved only for high achievers, and it categorizes high performers from low performers. On the other hand, underachievement is:

the point at which a certain level of accomplishment changes from being called achievement to underachievement, it varies from one grade to another, one school system to another, one teacher to another, and even one student to another... will be greatly influenced by the particulars of setting individuals and situation (Harvey \& Sander, 1988, p. 2)

Harvey \& Sander (1988) suggest that an underachiever must not be considered as a less competent learner, but learners could be of high, average or low ability; grades all alone are not a reliable indicator of the learners' real competencies. They propose a set of definitions under which underachievers are identified, because it is argued that school grades are but a judgmental number. 
Similarly, it has been claimed by many scholars that, within achievement, there are categories of learners. Some are considered as overachievers ${ }^{1}$, some as normal achievers and those who do not reach the average as underachievers.

Narayana (1964) tries to look for the distinction between the three types of learners based on four variables (mental ability, verbal ability, past performance and recent achievement). The results show that when achievement is high; the sense of responsibility in learners increases. Another study by Liddicoat (1973); Eisenman \& Platt, (1968) et al also reveal other qualities of underachievers as being more creative but have low reading comprehension and the instability of emotions, low inductive reasoning and memory (cited in Harvey \& Sander, 1988, pp. 16-19).

"Underachievement is a discrepancy between what can be expected and what is actually achieved" (McCoach \& Siegle, 2003b, 2011, as cited in Castejon et al., 2016, p. 01); in the educational context, there is a contradiction between pupils' abilities or skills and their performance, They have pointed out that if schools are addressing only good pupils, they should change this view and focus on the discrepancy between pupils' know-how-to-be and know-how-to-do. It is believed that many educators are able to identify the less able pupils, and this might have an effect on this category of learners since they would be at risk of being neglected, unnoticed and then excluded indirectly from school. Pupils are capable of determining whether a teacher is biased to a certain category of learners, or he/she is neutral and treat them all equally.

\subsection{Identifying Underachievers}

In Castejon's work, underachievers could not be detected unless a specific method is applied. There are three suggested methods proposed by Lan and Chan (2001), and McCoach and Siegle (2011). The first method is the absolute split method; it is applied on gifted underachieving learners. The researcher uses a system of limiting high performance and low performance through a top academic performance (top 5\%) and bottom academic performance (bottom 5\%). The simple difference method is the second method to select underachievers from achievers. This approach is based on the difference between the learners' performance rate and their ability score, once the discrepancy rate is greater, the learner is likely to be considered as an underachiever. Third, the regression method is considered as a more reliable method than the previous ones. It aims to detect the discrepancy between the learner's competence and his/her expected performance; if the learner deviates from the regression line of the good performance level, he/she is considered as an underachiever (cited in Castejon et al., 2016).

\subsection{The Inter-rater Agreement}

The system of assessing pupils at school is not conventional among schools (Martinkova \& Goldhaber, 2015); using grades to evaluate academic achievement poses many problems such as the lack of inter-rater reliability ${ }^{2}$ among instructors or schools about the way they should assess

\footnotetext{
${ }^{1}$ Overachievement: is not an accomplishment beyond an individual's own competencies; it refers to the perseverance of a learner to work hard where the majority of learners do not.

${ }^{2}$ Inter-rater agreement or concordance: is the degree of agreement among teachers concerning the way pupils are assessed.
} 
performance (Graham, Milanowski, \& Miller, 2012). Castejon (2016) suggests that instructors should agree on one exact rating of performance, and which performance is considered by teachers as good or bad. Though the current literature review highlights many factors which may push pupils backwards, but Castejon et al., (2016) and Yuan and Che (2012) put emphasis on personal factors which are linked to self-regulation ${ }^{3}$ and learning strategies ${ }^{4}$. They claim that, in the classroom context, it is observed that pupils with high performance and those with low performance do not behave similarly and even the way their attitudes towards their teachers differ from one pupil to another.

\subsection{Classification of Factors}

School, teachers, family and learning strategies are emotional and motivational factors which could affect pupils' performance (Maslow 1970; Pennell \& West 2003). Particularly, each factor may fall into one of the four main types: permanent, temporary, internal and external (Harvey \& Sander 1988). Educators should know their pupils as individuals in order to select which type of factors they will be dealing with; if the temporary factors, such as flu, can be skipped easily, a permanent factor, as the death of parents, needs a considerable time to be treated. Research shows that the performance of learners depends on a number of factors in which, learning facilities, gender and age of pupils are among them (Mushtaq \& Khan 2012). Another factor, as reported in the BBC news report, concerns the adherence to school orders. Sewell (2006), in an interview with the BBC news, believes that males who respect the school orders turn to be feminine in behaviour and their achievement is regarded as gender inappropriate by their mates, but if they do not follow the school orders, they are pushed indirectly to failure and then to dropout. Others like Leathwood \& Read (2009), Cook (2016) argue that the teaching methods are convenient to female pupils and might not be preparing males appropriately for academic challenges, and insist on the existence of a gender imbalance in education.

\subsection{Pupils' Social Background and Status}

Giavrimis and Papanis (2008), in their study, associate failure with the social background of learners and their social status claiming that "the problem of school failure affects mostly poor students and becomes an obstacle to a large part of this segment vulnerable population from making full use of their educational opportunities to improve their social status" (p, 328). They strongly put stress on the negative impact of poverty on learners' school feedback; poor background entails thinking about what to eat, what to wear but not what to learn to be an intellectual; that is to say, poor pupils are not interested in filling their schema with useful knowledge but become unconsciously indifferent. More than that, they state that failure at school can lead to detachment and social segregation by the society members. The dimension of school failure is not solely educational, but professional, economic, social and cultural. Learners who face complications at school find it difficult to be part in a competitive world whether at school or in the workplace; as a result, this category of pupils turns out to be doing

\footnotetext{
${ }^{3}$ Self- regulation: is a self-directive process by which learners transform their mental abilities into academic skills... it involves the self-awareness and self-motivation to implement that knowledge adequately.

${ }^{4}$ Learning Strategy: is a concept that refers to the processes that are consciously used by language learners to help them in learning or using a language effectively.
} 
kind of jobs with a mediocre income or of no worth (Giavrimis \& Papanis, 2008). "Fighting against school failure demands not just the application of "therapeutic" methods at school, but rather the participation of society as a whole" (Giavrimis \& Papanis (2008, p. 329).

On the contrary, Salameh (2012) claims that though economy might have a positive impact on pupils' performance but not all the time, in many cases it could affect the learner negatively and this can be observed through their unacceptable attitudes in the classroom with their classmate, the only aspect that may link high status with good performance is the pupils' mental satisfaction. "Economic prosperity or economic flow will ultimately enhance the performance level of a student towards learning, but the case is not always right, because sometimes the flow of economy makes a person rude and proud" (p. 13) teachers all alone cannot save learners from failing; parents, learners, and peer groups should have a role in improving education and encouraging future generations to do better (Kraft \& Dougherty, 2012).

\subsection{Learning a Foreign Language in a Bilingual Context}

Negadi (2015) stresses the importance of being bilingual in order to learn a foreign language efficiently especially if one of the languages shares similar lexis and grammar rules, in this prospect, he states that "French helps learners to develop proficiency in English through the transfer of their French-based background, in particular the typological (syntactical and lexical) similarities between French and English" (p. 496). Being competent and skillful in one variety is no more beneficial, but competence in more than one language becomes a necessity more than a pleasure (Al-Amri, 2013). Negadi (2015) proposes that when a speech community is bilingual and is in the process of learning a foreign language like English, there is a possibility of learning this variety using the French language as an intermediate code. Thus, there is a potential to create a learning context to teach English by means of another language, in our context, French.

"In the case of Algeria, an Arabic speaking country, it is possible to create a learning environment where English is taught by means of French... this study does not suggest that L1 (Arabic) delays achieving control over L3 (English), but assumes that French may be used as a facilitator leading the learner of English to gain time and energy" (Negadi, 2015, p. 497)

\subsection{The New Challenge for the Algerian Schools}

Benramdane (2017), in an interview with an Algerian Radio 'la redaction', claims that in order to reach quality in our schools we need to advance our system and improve performance through assessing learning in accordance with international standards 'le system scholaire Algerien doit être inscrit dans des logiques comparative international'. He puts emphasis on the awareness of the educational sector concerning the low level of pupils. Thus, the first step towards improvement, for him, is to enhance the teachers' training. He sheds light on the unfamiliarity of our society with the difference between school and educational system, in his words 'l'école est un espace de production de reproduction de la science... c'est un espace autonome des autres sphère politique, militaire, religieuse'; as for the system 'c'est le contenu' that changes through time, because of technological advancement, and scientific innovation. Benramdane declares that the Algerian society needs to be stabilized and people are debating 
only, year by year, on what is quantitative, as the number classes, number of teachers, number of pupils, but never on the qualitative, as the content of the input.

Benramdane (2017) raises a very significant quality in teachers, he argues that they should have the know and know-how-to-do, being competent in the field does not necessarily mean that this person is professional in teaching 'Le métier d'enseignant exige à la fois un savoir académique et un savoir-faire professionnel'. Actually, we can find a competent teacher in any field, but when it comes to transmitting knowledge to his/her learners, he/she fails. By contrast, there are elements who are not competent enough, but they are able to transmit knowledge successfully and make learners progress. In this vein, our system is at the crossroads between quantity and quality 'le système scholaire Algérien est a l'intersection de la quantité et de la qualité'. Similarly, Benabed (2015) stresses the important role that teachers play within CBA application arguing that they are challenged with teaching besides learning "what and how to teach in a speedy way" (p. 17). Further, because the $21^{\text {st }}$ century is in need of distinct competencies in comparison to previous decades, and as long as curriculum is concerned, teachers should take part in decision making because they are in direct contact with pupils and are quite familiar with the teaching difficulties; in this regard, they should be "at the core of this teaching/learning decision-making" (Benabed, 2015, p. 17). Hence, if their opinions are taken into account, they will be able to select the appropriate approaches and procedures that fit the learners' learning needs and preferences (Hanifi, 2011; Gherzouli 2016).

\section{Methodology}

\subsection{Participants and Research Setting}

Regardless of the social problems in the lives of many of the pupils in Mohamed Boudhiaf Secondary School, learners seem energetic and active, but most of them appear bored and indifferent in the classroom. Female pupils of third year seem excited and enthusiastic, whereas males seem inattentive and disinterested. Teachers display deep concern and commitment to their pupils and their learningmuch of the talk during breaks revolve around the pupils' behaviour, and the difficulties they face to transmit the message due to the negative feedback they receive from learners frequently.

The teachers' role in this school is quite important; they play the role of a mediator and a facilitator of knowledge. An interview with the principal takes place for an hour and a half. She agreed on the recurrence of failure among learners in foreign languages claiming that, from her experience as a teacher, pupils' family is a reason behind preventing them from using the foreign language outside school; because it is not used at home, it could not be used elsewhere fluently and correctly. An interview with the vice principal shows that during his 7 years of work, the level of pupils in foreign languages, especially English, has always been low and fixed, there is no improvement; as for the teaching materials (overhead projectors, laptops) they are used mostly by teachers of physics, maths and science. Additionally, the internet is not accessible in the institution, thus pupils cannot have access to information, except from books which are available in the school library, in all fields and for different streams.

The majority of teachers in this school are new because many experienced teachers have retired recently. As for the teachers of English, they have an experience in teaching from 11 years to 19 years of 
experience. This enables the researcher to be acquainted with how language has been taught to previous generations with changing mentalities, abilities and social background of pupils.

Among 273 pupils subscribed in the secondary school of Mohamed Boudhiaf, state of Tissemsilt, 82 pupils were chosen to undertake this research; thus the number of questionnaires distributed to third year secondary school pupils is 82 . Among 82 pupils, two of them were rejected because questions were not all filled. Our questionnaire is a mixture of close ended and open ended questions. The first part highlights demographic and organizational variables in which pupils give personal information about themselves. The second part revolves around detailed information which represents social and individual variables. The aim of the questionnaire is to provide the researcher with an insight about how learning takes place in this public school.

\section{Results and Discussion}

After the collection of data from the pre-selected sample, we highlighted on many factors which represent a real handicap to pupils' achievement at school and particularly in foreign languages. It is noteworthy to mention that written performance is always a step to pass into another educational degree. Table 1 below clarifies the success rate of pupils in 2018 baccalaureate examination at the secondary school of Mohamed Boudhiaf, including all streams. We can notice that the success rate is about $71 \%$ in which $48 \%$ are females whereas $23 \%$ are males. It is evident that females' success rate is higher than males. The failure degree is around $29 \%$ from the overall number of learners at this secondary school.

Table 1: Pupils' Baccalaureate success rate in Mohamed Boudhiaf Secondary School in 2018

\begin{tabular}{|c|c|c|}
\hline Genders & Number & Percentage \\
\hline Males & 19 & $23 \%$ \\
\hline Females & 39 & $48 \%$ \\
\hline Total & 58 & $71 \%$ \\
\hline Failure rate & 24 & $29 \%$ \\
\hline Overall Number & 82 & $100 \%$ \\
\hline
\end{tabular}




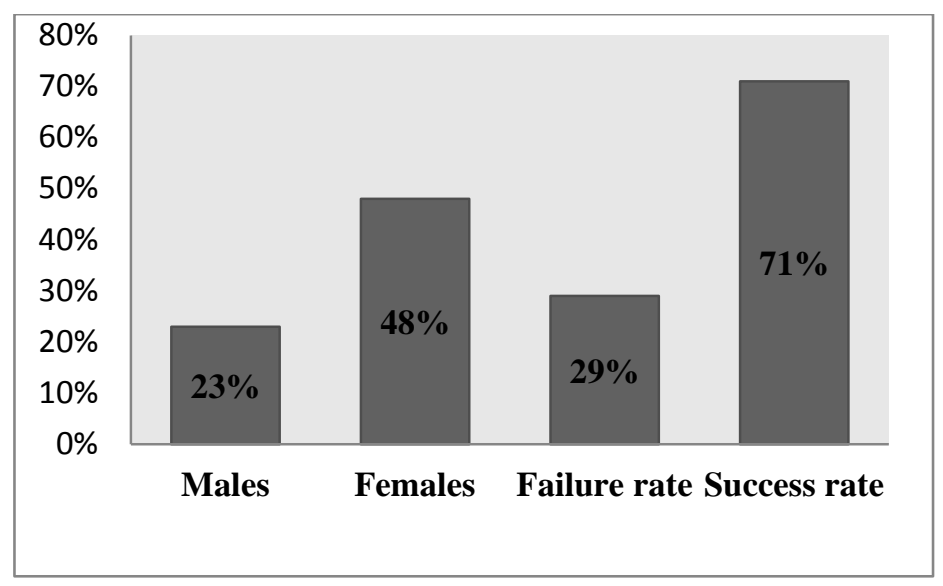

Figure 1: Success rate in Mohamed Boudhiaf Secondary School

First of all, as clarified in Figure 2 below, $6 \%$ has 16 years old, $42 \%$ has 17 years old, $49 \%$ has 18 years old, and 3\% has more than 18 years. Actually, these pupils have studied for 5 years in the primary school in comparison to older generations in which 6 years of learning was mandatory. In the classroom, their behaviour is childish, they are eager to play more than paying attention to their instructors, this is observed in all the streams, even in the foreign languages stream in which English has a high coefficient. In fact, there is a gap between their age and their teachers' age and experience, the majority of pupils are well versed in how to use technology like Smart phones in which all of them has and use secretly in the classroom. Actually, there is a clash between a well acquainted learner with digital means and a classroom in which lectures are traditional par excellence.

Table 2: Pupils' distribution by age bracket

\begin{tabular}{|c|c|c|}
\hline Age & Number & Percentage \% \\
\hline 16 years old & 05 & $6 \%$ \\
\hline 17 years old & 34 & $42 \%$ \\
\hline 18 years old & 39 & $49 \%$ \\
\hline More than 18 & 02 & $3 \%$ \\
\hline
\end{tabular}




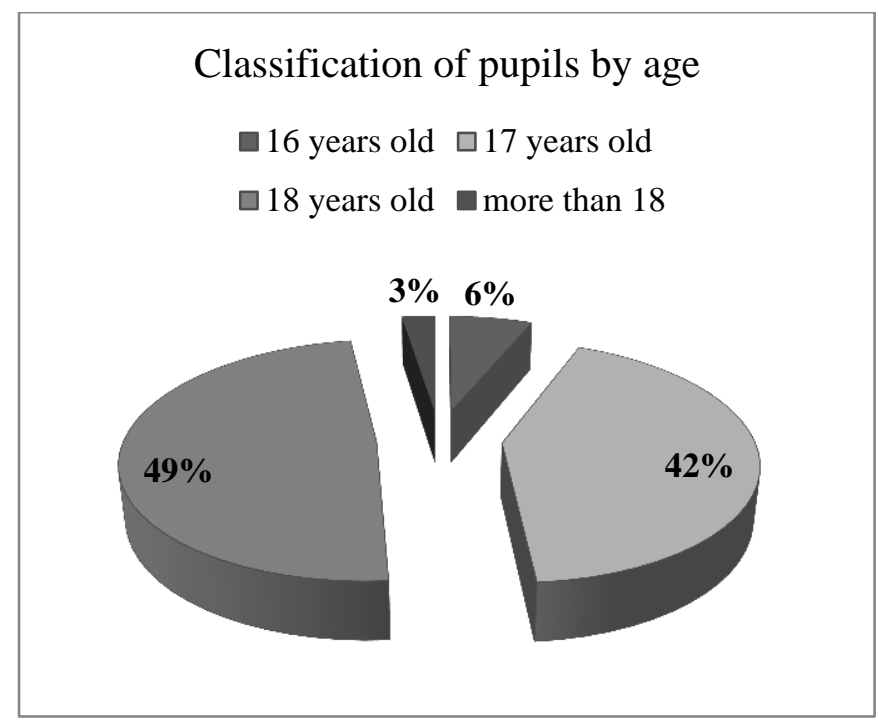

Figure 2: Compilations of learners by age

Second of all, the father is the one who is responsible for his children's living; $4 \%$ our sample shows any responsibility to be taken in their young age that could represent an obstacle in their learning. However, females are motivated to learn because they want to be independent and help their parents in sharing responsibility; males reveal their obligation to do it; education is not important for them because they strongly believe that they will reach a dead end with studying; that is why, most of them show indifference in the classroom, whereas enthusiasm and attentiveness were the qualities of females in this school. More than that, our sample mothers, the majority, are not educated and do not work outside, but are housewives. Though most pupils articulate that they are forced by their parents to study, but unfortunately most of parents do not attend the day of fathers scheduled at school, they show up only if their child obtains a bad mark by the end of the semester.

Table 3: Parental home charge

\begin{tabular}{|c|c|c|}
\hline Option & Number & Percentage \\
\hline The Father & 71 & $88,75 \%$ \\
\hline The Mother & 06 & $7,5 \%$ \\
\hline You & 03 & $3,75 \%$ \\
\hline Total & 80 & $100 \%$ \\
\hline
\end{tabular}




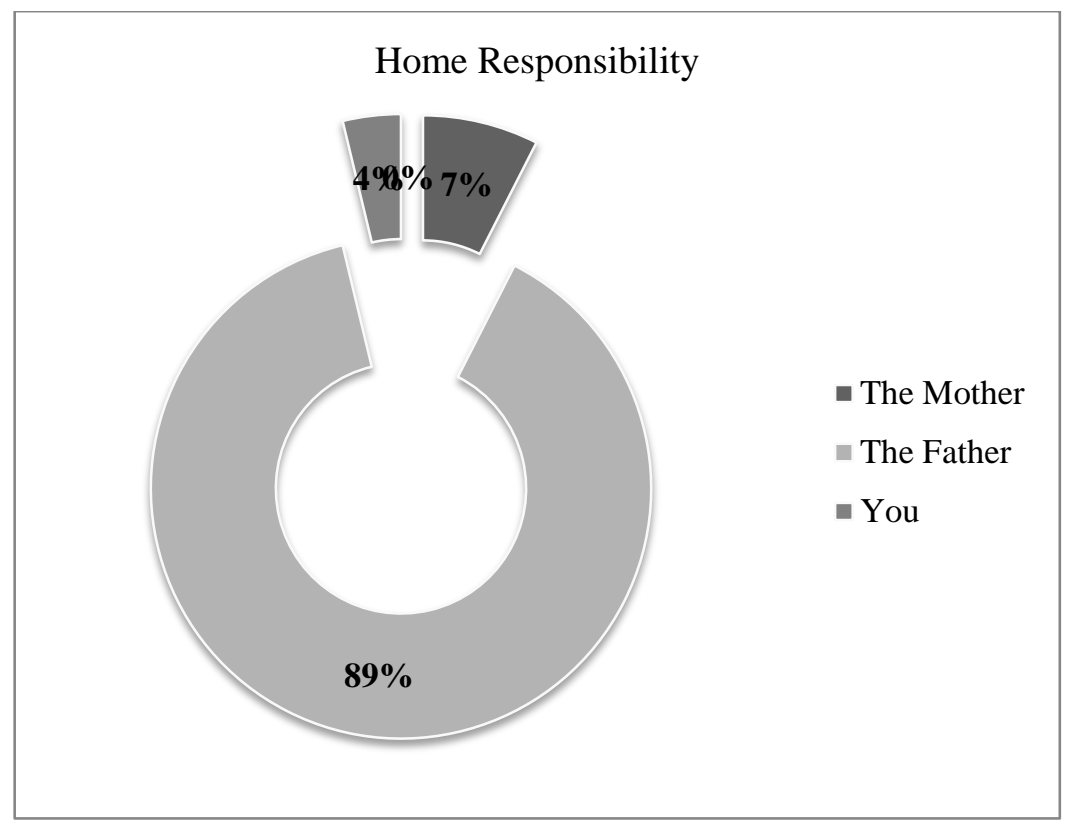

Figure 3: Parents' liability at home

Third of all, as mentioned in Figure 4 below, $46 \%$ of pupils selects Arabic as a favourite school subject while $21 \%$ chooses English. 23\% prefers French whereas $10 \%$ goes for Spanish. English is not considered as an interesting subject by pupils in all streams. However our sample has the tendency to watch English movies and songs, but still what is taught in the classroom does not interest them most of the time. For this, English is not the only language used by the teachers of English to transmit information, but Arabic and French are used alternatively to clarify any ambiguity, especially with difficult concepts in the syllabus. The problem is that pupils think in Arabic, they do not understand the lesson in English; they need at least hints in another language to grasp what the lecture is all about, especially because the lectures are traditional, ICTs are rarely used, and the school book is the only resource of information. Accordingly, the teachers' reason behind this latter is that using any technological material causes noise and distraction in the classroom. Hence, they believe that one hour is not enough to cover the whole lecture and finish the syllabus on time. Though the Algerian context is multilingual whereby Arabic, French, Tamazight and other varieties are used, but in the classroom context the mother tongue (Arabic) is used most of the time to explain the lectures if the situation needs the variety's intervention. 
Table 4: Learners' language preference in Mohamed Boudhiaf

\begin{tabular}{|l|c|c|}
\hline Language & Number & Percentage \\
\hline English & 17 & $21,25 \%$ \\
\hline Arabic & 37 & $46,25 \%$ \\
\hline Spanish & 08 & $10 \%$ \\
\hline French & 18 & $22,5 \%$ \\
\hline Total & 80 & $100 \%$ \\
\hline
\end{tabular}

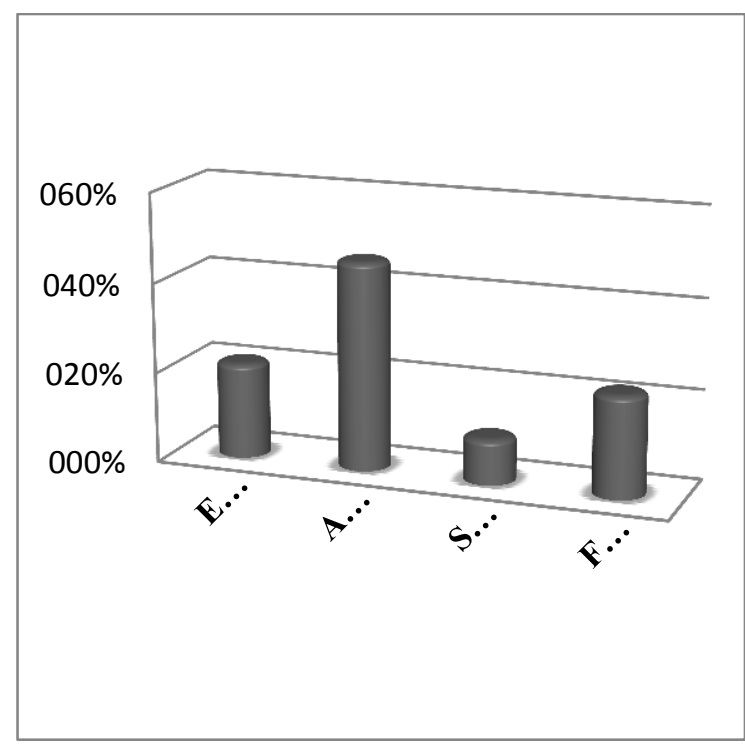

Figure 4: Language subject preferences in the secondary school

Fourth, during our stay in this school, we have observed coordination among teachers; they attend sessions as if they are newly recruited to improve their teaching skills. They claim that in comparison to written performance like tests or exams, pupils' oral contribution is better; however it is not that satisfactory. Females' written performance is better than males' performance. And this is over years, among different generations and different streams. Teachers claim that pupils face difficulties in understanding, especially in the situation of integration, in which grammatical and syntactic errors are made. For this, they put all the blame on middle school teachers, who are supposed to equip learners with the basic grammatical structures of the English language.

Additionally, the majority of pupils confirm that their school success or failure is not related to their teachers' gender, whether a male or female, it is not a serious problem. But, the number of female pupils in each classroom in comparison to males affects their oral and written performance. Adolescent males, psychologically speaking, feel ashamed if they make mistakes in front of females, thus they prefer to 
keep quiet instead of being embarrassed in public. Furthermore, they believe in the idea that females are always in the foreground; their chances are high wherever they are.

Table 5: Learners' perspectives towards school drop-out

\begin{tabular}{|l|l|l|l|l|}
\hline Option & Yes & $\%$ & No & $\%$ \\
\hline Males & 17 & $21 \%$ & 16 & $20 \%$ \\
\hline Females & 36 & $46 \%$ & 11 & $14 \%$ \\
\hline
\end{tabular}

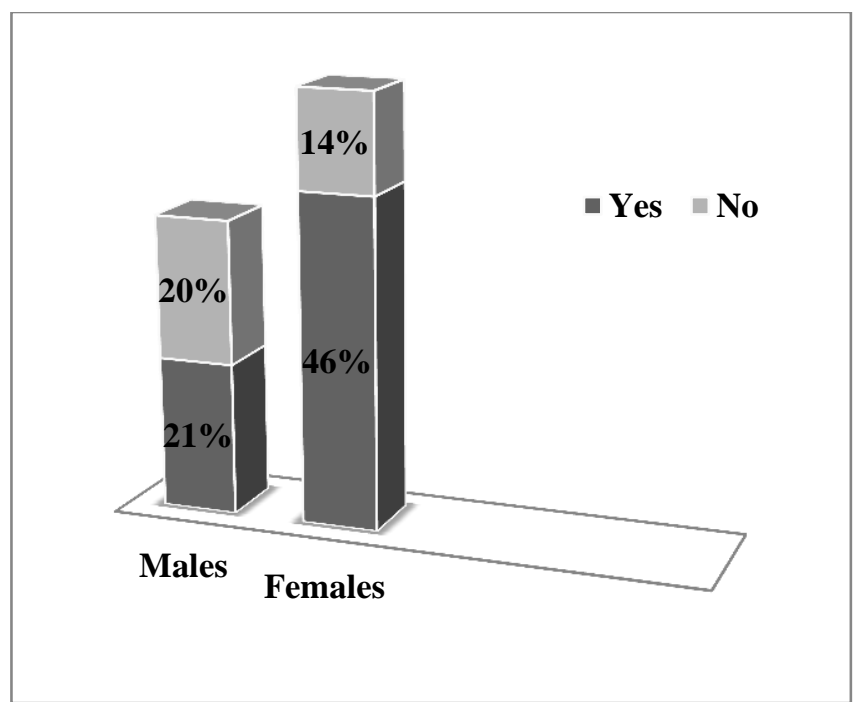

Figure 5: Pupils' drop-out perception

Table 5 and Figure 5 above indicate the extent to which our selected sample fear school dropout, actually, $20 \%$ of males responds negatively to our question claiming that their school drop-out is not a serious problem, $21 \%$ of males argues that they fear drop out, though when answering they seem indifferent as well. As for females, the majority show their fear from school failure and drop out, $46 \%$ of females reveals a negative standpoint towards drop-out; however, $14 \%$ of females replies with 'no', and reveal their indifference. For male pupils, the category that shows no fear from dropping out of school, claims that studying would not offer them a good future and military service is an alternative plan, it is the only path whereby money is earned easily; some argue that females are taking a recognized position everywhere, so they are pre-programmed that there is no future neither at school nor in the workforce in comparison to a female. The group of males that displays fear from this latter, their explanation is that school is the future and they fear the reaction of their parents; thus they avoid failing at school in order to realize their parents' dreams, though they are few. On the contrary, female pupils, the ones who fear drop out justify their answers through their motivation to learn, earn a degree, get a decent job and realize their dreams, they express their love to learning, to their teachers and their school, the only thing that urge them to fear failing is the obligation of their parents to get married at a young age. The category that answers negatively claims that school is not everything so failing is not the end of the world for them. Others explain that they do not fear drop out because they show confidence that they will not fail because they are serious and hard workers. It is noteworthy to mention that, the social 
environment where these pupils live has a strong impact on the way they think. Teen marriage is what depicts the environment especially if a female quit school early; and military service is the preference of the majority of males at an early age.

\section{Conclusion}

Underachievement is a phenomenon that is observed among pupils in Mohamed Boudhiaf Secondary School, final classes in Tissemsilt-Algeria. Male pupils underachieve in class in comparison to female pupils. Pupils' social background and gender strongly affect their performance. Learners at this school are energetic but indifferent. The majority of them already studied five years in the primary school; their age and behaviour inside the classroom, and in the yard, show their willingness to play rather than to study. Additionally, in comparison to male pupils, females seem enthusiastic and interesting in learning; their place in the front and their participation with the teacher is a proof for this. Besides, arranged marriage at an early age is what makes them concerned, for this reason, they try hard to avoid failure. For them, education means freedom of expression and choice. It is noteworthy to recall that pupils' linguistic background and the school culture are not alike especially in the context of learning a foreign language like English, i.e. English is not used outside school, and this represents a difficulty for pupils to be familiarized with what their teachers of English are saying, particularly when not using the projector or even printed pictures; thus the description of concepts is virtual and theoretical. However, the teachers of English try all their best to improve the achievement of pupils, especially when shifting back and forth between English, French and Arabic to clarify any ambiguity, but the social background and the psychological problems that most teenagers face influence their learning process, without forgetting to mention the impact of the social environment of learners whereby teen marriage and military service are a tendency in the province.

NB: The results of this work are based on the questionnaire results from the secondary school of Mohamed Boudhiaf, Khemisti, Tissemsilt- ALGERIA.

-The success rate in the Baccalaureate examination is taken from the official website of the Directorate of National Education.

\section{References}

Al-Amri, N. M. (2013). Effects of bilingualism on personality, cognitive and educational developments: A historical perspective. American Academic \& Scholarly Research Journal, 5 (1), 1-7.

BBC News (2006, June 13). Schools 'too feminine for boys'. Retrieved from http://news.bbc.co.uk/2/hi/5074794.stm

Benabed, A. (2015). The didactic issues of the Algerian English teachers' initial and in-service training courses: Between institutional objectives and teachers' expectations. Published Doctoral dissertation, Djillali Liabés University, Sidi Belabess.

Castejon, L., Gilar, R., Veas, A., \& Minaxo, P. (2016). Differences in Learning Strategies, goal orientations and self-concept between overachieving, normal-achieving and underachieving secondary students. Frontiers in Psychology, 7, 1-13, doi: 10.3389/fpsyg.2016. 01438.

Curnock, C. (2016). Our education system must stop ignoring its bias against boys. Retrieved from www.telegraph.co.uk/men/thinking-man/our-education-system-must-stop-ignoring-its-biasagainst-boys/ 
Gherzouli, K. (2016). Action research for curriculum development: An alternative approach in the Algerian centralised framework, University of Mentouri Constantine. Revue des Sciences Sociales, 23, 58-74.

Giavrimis, P., \& Papanis, E. (2008). Sociological dimensions of school failure: The views of educators and students of educational schools, The Journal of International Social Research, 1 (5), 327 354.

Graham, M. Milanowski, A. Miller, J. (2012). Measuring and promoting inter-rater agreement of teacher and principal performance ratings. US: Center for Educator Componsation Reform.

Hanifi, A. (2011). Specificities of scientific texts' reading in the secondary school: The case of third secondary school students in Mediouna lycée/Relizane. University of Hassiba BenboualiChlef, Algeria.

Harvey, P., \& Sander, I. (1988). The psychology of underachievement: Differential diagnosis and differential treatment. Canada: A Wiley-Inter science publication.

Griffin, S. (1988). Underachievement in secondary school: Education off the mark. New York and London: Routledge, Taylor and Francis Group.

Kraft, A. M., \& Dougherty, M. S. (2012). The effect of teacher-family communication on student engagement: Evidence from a randomized field experiment. Journal of Research on Educational Effectiveness, 6(3), 199-222.

Leathwood, C., \& Read, B. (2009). Gender and the changing face of higher education: A feminized future? London: Society for Research into Education and Open University Press.

Martinkova, P., \& Goldhaber, D. (2015). Improving teacher selection: The effect of inter rater reliability in the screening process. CEDR Working Paper 2015-7. University of Washington, Seattle, WA.

Maslow, A. H. (1970). Motivation and personality. Publishers: Harper \& Row.

Mushtaq, I., \& Khan, N, S. (2012). Factors affecting students' academic performance. University Islamabad, Pakistan. Global Journal of Management and Business Research, 12 (9), 17-22.

Negadi, M. N. (2015). English in Algeria through French-based background proficiency. University of Tlemcen. GlobELT: An International Conference on Teaching and Learning English as an Additional Language, Antalya - Turkey Procedia - Social and Behavioral Sciences, 199, 496500.

Pennell, H., \& West, A. (2003). Underachievement in schools. London and New York: Routledge Falmer,Taylor and Francis group.

Radio Algérienne. (2017). Farid Benramdane conseiller auprès de la ministre de l'éducation nationale. Retrieved September 16, 2018, from https://www.youtube.com/watch?time_continue $=1796 \& \mathrm{v}=6 \mathrm{VxPjHUFPjk}$

Salameh, W. (2012). The impact of social and economic factors on students' English language performance in EFL classrooms in Dubai public secondary schools. The British University in Dubai, Faculty of Education.

Yuan, X. and Che, L. (2012). How to deal with student misbehavior in the classroom? Journal of Educational and Developmental Psychology, 2 (1), 143-150. 